\title{
ENVIRONMENTAL IMPACT OF TRANSPORTATION IN THE TOURISM INDUSTRY - DIMENSIONS AND ACTIONS
}

\author{
Mirela Ștefănică \\ Al. I. Cuza Univ of Iași, Faculty of Economics and Business Administration \\ stefanicamirela@yahoo.com
}

\begin{abstract}
The development of tourism and the increase in the number of travellers at the level of certain areas of touristic interest brings socio-economic benefits and also leads to the damaging of the quality of the environment. Transportation, as component of the tourism industry, has many side effects on the environment due to carbon dioxide emissions, pollution, etc. The work mainly emphasizes the way in which air, road, rail and water transportation influences the quality of the environment, contributing to global warming at the same time. Climate change, a consequence of global warming, is perhaps the biggest problem of the beginning of the millennium, representing one of the most prodigious forces that will affect the progress of humanity in the $21^{\text {st }}$ century and later. In this sense, our paper tries to draw attention to the adaptation measures meant to diminish the vulnerability of climate change at the level of tourism, in general and transportation, in particular.
\end{abstract}

\section{Keywords}

tourism; impact; environment; transportation in tourism; global warming; climate change

\section{JEL Classification}

L83; R49; Z32

\section{Introduction}

The first attempts to define tourism, as economic and social phenomenon go as back as the half of the $19^{\text {th }}$ century. Meanwhile, tourism-related activities developed rather slowly; however there was a boost in the 1960s when tourism turned in a true "phenomenon specific to the modern world" that became the first world "industry" due to the great impact of the activities in the 1960s, the creation of the raw product worldwide and of jobs (Jugănaru, 2007).

Thus, referring to tourism as industry, we mention that it is the part of the economy made up of a series of activities from various branches whose common function is to satisfy tourists' needs. The tourism industry contains the following:

- Accommodation sector: hotels, motels, guest houses, farms, cruise ships, villas, castles, camping, time-share properties, secondary residences;

- Food sector: restaurants (classic, traditional, fast-food), bars, cafés;

- Transportation sector: commercial sector represented by airlines, travel by ship, railway, road (coaches) and non-commercial sector consisting of private cars, planes and yachts;

- Travels sector: travel agencies and tour operators;

- Entertaining sector: gambling, clubs and discos, theme parks;

- Information sector: tourist information network;

- Additional services, facilities and infrastructure services.

Therefore, tourism has a complex content, it comprises not only the resources meant to ensure touristic circulation, but also the economic sectors that directly compete to satisfy touristic demand and needs. 
But on the other hand, tourism is mainly based on the valuing of touristic resources, and the level and intensity of this valuing lead to a series of side effects on the environment, in space and time. These effects are expressed by means of the notion of impact (Cândea et al, 2003).

According to Europe's Environment: the Third Assessment (EEA 2003), the direct impact of touristic activities on people and the environment at local level is strongly influenced by the intensity in time (periodicity) and space. Such impact is caused by:

- the intensive use of water and lands by leisure and touristic activities;

- the provision and use of energy resources;

- the changes of the natural framework occurred further to the construction of infrastructure, buildings and various facilities;

- air pollution and waste;

- soil compaction and impermeabilization;

- the disturbance of fauna and local inhabitants (e.g. due to noise pollution)

The direct impact on natural resources, either renewable or not, owing to touristic facilities, roads and airports, may be caused by the use of lands for accommodation facilities, other infrastructure plans and to extract construction materials (such as sand extraction).

\section{The Impact of Transportation in Tourism on the Environment} Transportation is essential for the tourism industry, and for the daily life of population; it represents the first manifestation of touristic consumption and is the only component of tourism industry that the tourist cannot do without. It ensures the travel between one's home and the touristic destination or other facilities specific to the tourism activity.

Thus, transportation services in the tourism industry, apart from the overall operations, aim at the conditions and facilities related to the organisation ofthe transportation of tourists and their luggage (Minciu, 2000), a series of activities meant to facilitate the achievement of the other touristic services (technological transportation necessary for accommodation, meals and leisure).At the same time, the technical success recorded in transportation afforded unprecedented growth of the touristic flow and considerably increased the power to access isolated destinations (Matei, 2004).

Recently, there is mainly air and road transportation in tourism (over $40 \%$ of the total amount for each), railway and water transportation being lower in percentage (around 7-8\%), according to Tourism Market Trends: Europe - 2000.

In what follows, we present the main side effects on the environment of the various means of transportation used in tourism.

\section{The Impact of Railway Transportation in Tourism on the Environment}

In the late $20^{\text {th }}$ century and early $21^{\text {st }}$ century, the railway transport of passengers and travellers fell in demand because of the competition with other modes of transport. Furthermore, the lack of standardisation between states makes impossible a direct relation between them (gaps, electrification), not to mention the restrictions on network development due to the configuration of landforms, water-dry land division, the high price for their maintenance, financial inefficiency on some lines, the need for subsidies, especially governmental ones. Despite all these, in some areas on the planet, the railway network modernised: ever since 1965 Japan has introduced high-speed trains in big cities - shinkasen, ground effect trains - maglev and Europe has almost 200 cities related by EuroCity, TGV, Intercity, railbus, Eurotunnel - 1994, to which we can add the facilities for international tourists via Eurailpass. 
For the environment, this mode of transport has a relatively low impact shown in vibrations, the rise of anthropic landforms (e.g. embankments and excavations) and the likely electrostatic or electrical pollution of electrified tracks.

\section{The Impact of Road Transportation in Tourism on the Environment}

The tourism industry is favoured by the development of road transportation due to the different modes of transport: buses, coaches, maxi-taxi and especially cars. Cars are the most employed mode of transport and they continually gain in popularity for the following reasons (Ferent, 2007):

- greater flexibility in choosing transportation routes;

- the tourists' desire to know more in a shorter time, which is essential for the comfort of travelling and sometimes as far as distance is concerned;

- allow an increased accessibility of isolated sightseeing spots and greater ease in luggage transportation;

- increase the tourist's feeling of independence;

- a diminution of the cost per tourist against the background of the increase in the occupancy degree of the mode of transport.

Regarding the relation between these modes of transport and the environment, it is important to mention the great and multiple impact they exert: $\mathrm{CO}, \mathrm{SOx}, \mathrm{NOx}$, lead, HPA emissions, other volatile compounds, sound and soil pollution, land consumption for infrastructure, as well as accident risks.

\section{The Impact of Water Transportation on the Environment}

Tourism employs water transportation especially via cruise ships that ensure both the transport and accommodation or destination in the same place. The touristic attraction is the mode of transport itself as it benefits from the services mentioned above and other facilities: meals, shopping, sports games, pools, dance, theatre, films, conference rooms, library, thus becoming a genuine floating resort.

Approximately 20 million passengers embarked on a cruise ship in 2016 worldwide, as compared to only 0.5 million in 1970. Moreover, on the tourism market, there is an increase in the use of ferryboats, yachts, motor scooters, hovercrafts (Great Britain, Alaska), kayak-canoe, boats that are both touristic attractions or entertainment.

For the environment, the impact of these modes of transport is related to accident risks, the behaviour of tourists or personnel in tourism with respect to the management of materials used on the mode of transport and the eco-technical equipment of the boat or the diving schedules in the sea that may endanger the marine life.

Bluewater Network Association claims that a voyage that lasts for a week on a regular ship is responsible for the generation of 4.5 trillion litres of "grey waters", 50 tons measured in garbage metres, over 200000 tons of waste and 160000 litres of oil contaminated water. Wherever they get (and unfortunately most of them reach the sea), pollution problems occur. The effect of cruise ships on communities visited seems to be ambivalent as there are few important tangible benefits for the locals.

\section{The Impact of Air Transportation on the Environment}

Air transportation is one of the most popular modes of transport due to low travelling time, high comfort, online reservation system; however, there are some disadvantages given the perceived risk of accidents (although world statistics shows that is the safest mode of transport equipped with devices for detecting dangerous objects on boarding, highly qualified personnel, aeronautical technology), because of terrorism acts, fixed timetables, expensive tickets, etc.

For the environment, air transportation is identified as one of the cause of global warming, the depletion of the ozone layer, and via airports, it becomes a major chemical 
pollution source for the air in the tangent residential areas, and is responsible for sound pollution, as well.

According to the Aviation Environment Federation (AEF), short economic flights incur 300-460g of CO2 per kilometre, whereas long distance flights, 210-330 g. At present, international flights increased by more than $5 \%$ per year (short distance flights in the Asia-Pacific region by $8 \%$, the European ones by $5 \%$ and the USA ones by $3 \%$ ) (Adam, 2007).

\section{The Contribution of Tourism and Its Transportation to Global Warming}

Global warming is the phenomenon responsible for the increase of average temperatures in the atmosphere nearby the soil, as well as in oceans. It started to worry us after the 60s further to massive industrial development and the increase of the concentration in greenhouse effects held responsible for this phenomenon (Stănciulescu $\&$ Micu, 2012).

In 2004, David King, the British Government's Chief Scientific Advisor of the time as reputed scientist, underlined that climate change, a consequence of global warming, was the most serious problem of the entire humanity, much more serious than terrorist threats.

Before often exacerbated nationalisms, religious and cultural gaps, ethnic identity and welfare levels between people, global warming often reminds us more than anything else of the only thing we have in common - the Earth. By its impact on the planet's ecology, rain falls, temperature and weather patterns, global warming will affect the life of every one of us in part. Before our very eyes, Earth temperature is growing, the quantity and distribution of rain falls changes, ecological areas migrate, seas and oceans get warmer, ice caps and glaciers are melting and millions of people are worried about the future (Watkins, 2008).

The continuous rise of international travels amounting to hundreds of millions and the billions of internal travels in the recent years according to statistics largely contribute to the increase of greenhouse effects; at the same time, the tourism sector is vulnerable in front of climate change.

A UNWTO report establishes a link between tourism and climate change. The main conclusions of the study are the following:

- carbon emissions from transport, accommodation and other touristic activities are estimated at 4-6\% from the total amount of carbon dioxide emissions;

- because of the lack of measures against them, carbon dioxide emissions from this sector could rise by $150 \%$ in the following 30 years;

- the impact of climate change on tourism will increase along with greenhouse effects. Climate change can affect important touristic areas in which climate is of utmost importance such as Northern Europe, the Mediterranean or the Caribbean;

- coastal, mountain areas and the wild regions in the less developed countries and small islands will be particularly affected;

- the tourism sector will need to be able to cope with the changes mainly in the endangered areas by the substantial diminution of emissions via new technologies and financial mechanisms.

Consequently, the tourism industry contributes to global warming especially by means of carbon dioxide emissions of planes and cars (that ensure both the transportation of tourists and of the products necessary to satisfy their needs once arrived at their destination), as well as the use of energy (which is vital for any accommodation unit or one that provides meals, for technological processes and for the customers' personal use) and the fuel necessary for various installations (liquid and gas fuels being used for the preparation of domestic hot water, central heating, technological steam for professional washing/ cleaning services, etc.). 
In addition, the change of the destination in certain lands, i.e. the excessive urbanisation of some touristic interest areas or the deforestation carried out for building infrastructure specific to tourism development contribute to the volume increaseof greenhouse effects.

\section{Measures for the Diminution of Climate Change}

To diminish the vulnerability of climate change, specialists proposed a series of adaptation measures corresponding to every sector, as can be seen from table 1 below.

Table 1Measures for the Diminution of Climate Change

\begin{tabular}{|c|c|c|c|}
\hline Sector & $\begin{array}{c}\text { Adaptation } \\
\text { strategy }\end{array}$ & Action framework & $\begin{array}{c}\text { Positive and negative } \\
\text { factors }\end{array}$ \\
\hline Tourism & $\begin{array}{l}\text { Diversification of } \\
\text { touristic } \\
\text { attractions } \\
\text { Transport to ski } \\
\text { slopes at high } \\
\text { altitudes and } \\
\text { glacial lakes } \\
\text { Production of } \\
\text { artificial snow }\end{array}$ & $\begin{array}{l}\text { Integrated planning } \\
\text { (the capacity of } \\
\text { touristic } \\
\text { accommodation } \\
\text { links to other } \\
\text { sectors) } \\
\text { Financial measures } \\
\text { (subsidies, credits) }\end{array}$ & $\begin{array}{l}\text { Demand for new } \\
\text { touristic attractions } \\
\text { Financial and logistic } \\
\text { problems } \\
\text { Side effects on other } \\
\text { sectors (e.g. increased } \\
\text { consumption of } \\
\text { energy for the } \\
\text { production of artificial } \\
\text { snow) }\end{array}$ \\
\hline Transportation & $\begin{array}{l}\text { Norms for route } \\
\text { design and } \\
\text { planning } \\
\text { Railways and } \\
\text { other } \\
\text { infrastructure } \\
\text { elements }\end{array}$ & $\begin{array}{l}\text { National } \\
\text { transportation } \\
\text { policies considering } \\
\text { the effects of } \\
\text { climate change }\end{array}$ & $\begin{array}{l}\text { Financial and } \\
\text { technological } \\
\text { obstacles } \\
\text { Amelioration } \\
\text { technologies and } \\
\text { integration in essential } \\
\text { sectors (e.g. energy) }\end{array}$ \\
\hline Energy & $\begin{array}{l}\text { Consolidation of } \\
\text { air transportation } \\
\text { networks } \\
\text { Energy efficiency } \\
\text { Promoting the use } \\
\text { of energy from } \\
\text { renewable } \\
\text { sources }\end{array}$ & $\begin{array}{l}\text { National energy } \\
\text { policies } \\
\text { Fiscal and financial } \\
\text { regulations } \\
\text { Norms to prevent } \\
\text { the effects of } \\
\text { climate change }\end{array}$ & $\begin{array}{l}\text { Financial and } \\
\text { technological } \\
\text { obstacles } \\
\text { Stimulation of new } \\
\text { technologies } \\
\text { Use of local resources }\end{array}$ \\
\hline
\end{tabular}

Source: Stănciulescu, G., Micu C., (2012), Managementul operațiunilor în hotelărie și restaurație, București, Ed. C.H. Beck, p.390

According to the table above, the tourism sector contributes to global warming by carbon dioxide emissions of planes and cars, as well as by the use of energy for installations. For this reason, all the people involved in the tourism industry are responsible and need to find solutions so as to adjust to climate change and limit its effects.

\section{Conclusions}

As previously mentioned, air and road transport are gaining in popularity, alongside with the increase in the number of tourists and their mobility. At present, tourism represents more than $60 \%$ of all air travels, so it is responsible for a more important 
quota with respect to dangerous gas emissions such as carbon dioxide. Emissions from modes of transport, electric energy-related ones are strongly connected with acid rains, global warming and serious phenomena of local pollution.

Sound pollution from air transportation, cars, motorcycles, buses and leisure vehicles such as snowmobiles, ski jets, ATVs are an increasing problem of tourism that causes irritation, stress or even hearing loss.

In conclusion, transportation in tourism has a significant impact on the environment, either direct or indirect by energy consumption, fossil fuels, the materials used to obtain modes or means of transport, terminals, space consumption, pollution with effect on global warming, acid rains, depletion of the ozone layer, disturbance of ecosystems by traffic jams or sound pollution.

\section{References}

Adam D., (2007), Flights reach record levels despite warnings over climate change, The Guardian, 9 mai 2007, p.3

Cândea M., Erdeli G., Simon T., Peptenatu D., (2003), Potenţialul turistic al României şi amenajarea turistică a spaţiului, București, Ed. Universitară, p.318

Ferenţ E., (2007), Economia şi managementul turismului, Iaşi, Ed. Politehnium, p.149 Jugănaru D.I., (2007), Politici şi strategii în turismul mondial, București, Ed. Expert, p. 17

Matei E., (2004), Mediul şi turismul, București, Ed. Credis, pp.30-33

Minciu R., (2000), Economia turismului, București, Ed. Uranus, p.233

Stănciulescu G., Micu C., (2012), Managementul operațiunilor în hotelărie și restaurație, București, Ed. C.H. Beck, p.390

Watkins K., (2008), în Raportul UNDP (Programul Naţiunilor Unite pentru Dezvoltare) pentru 2007/2008

Witt St., Brooke M., Buckley P., (1995), The Management of International Tourism, New York, Routledge, p. 24

***Tourism Market Trends: Europe - 2000, (2000), World Tourism Organization, Madrid, p. 15

***United Nations World Tourism Organization - Climate Change and Tourism: Responding to Global Challenges 